\title{
Antifouling activity as a function of population variation in Sargassum vulgare from the littoral of Rio de Janeiro (Brazil)
}

\author{
Erwan Plouguerné • Claire Hellio • Criscia Cesconetto • \\ Marie Thabard · Kim Mason • Benoît Véron • \\ Renato C. Pereira • Bernardo A. P. da Gama
}

Received: 14 October 2009 / Revised and accepted: 10 February 2010

(C) Springer Science+Business Media B.V. 2010

\begin{abstract}
The brown seaweed Sargassum vulgare is abundant along the coast of Rio de Janeiro state. An investigation of the spatial variation of antifouling activity was conducted, in which algae were collected at five locations along the coast of Rio de Janeiro during October 2008. Hexane, dichloromethane, methanol and acetone/water extracts were prepared and screened for their bioactivities against the growth of five strains of marine fouling bacteria, five biofilm-associated microphytobenthic strains and attachment of the mussel Perna perna. The most active were the hexane extracts from Bananal algae that inhibited the growth of all microalgae tested; the methanol and dichloromethane extracts from Mar do Norte, which inhibited Vibrio aestuarianus and Pseudoalteromonas elyakovii and the polyphenol extracts from Ilha de Itacuruçá and Bananal that inhibited mussel attachment, respectively, by $64 \%$ and $71 \%$ compared to controls.
\end{abstract}

Keywords Antifouling · Biofilms · Sargassum vulgare . Perna perna $\cdot$ Geographical variation · Polyphenols

E. Plouguerné $(\bowtie) \cdot$ C. Cesconetto $\cdot$ R. C. Pereira

B. A. P. da Gama

Laboratório de Produtos Naturais e Ecologia Química Marinha,

Departamento de Biologia Marinha, Instituto de Biologia,

Universidade Federal Fluminense,

Niterói 24001-970, Brazil

e-mail: eplouguerne@hotmail.com

C. Hellio $\cdot$ M. Thabard $\cdot$ K. Mason

School of Biological Sciences, King Henry Building,

University of Portsmouth,

Portsmouth PO1 2DY, UK

B. Véron

UMR 100 IFREMER-UCBN and Algobank-Caen,

BP 5186, 14032 Caen cedex, France

\section{Introduction}

Marine biofouling is defined as the adhesion of microbial slime, macroalgae and invertebrates such as barnacles, mussels and sponges on every immerged surface. The implications of this phenomenon are various, and many sectors such as aquaculture and the shipping industry have to face the consequences of biofouling. As an example, marine biofouling on ship hulls augments fuel consumption, hull drag and consequently cleaning and painting, resulting in estimated costs of ca. one billion dollars per year for the US Navy alone (Callow and Callow 2002). In addition, fouled hulls and propeller blades increase engine effort, increasing the emissions of carbon dioxide, therefore significantly contributing to global warming (Hellio and Yebra 2009).

Marine organisms are themselves affected by biofouling in the process known as epibiosis (Wahl 2008). The colonisation of their surfaces can lead to a change from a planktonic to a benthic existence, a shift from a motile to a sessile life form or the initiation of pathogenesis and eventually the death of the host (Steinberg et al. 2002). Marine organisms have developed mechanisms to cope with fouling, including mechanical defences (moulting or sloughing, grooming), physical defences (surface tension, microtopography) or chemical defences (surface $\mathrm{pH}$, bioactive compounds; Stoecker 1978; Davis et al. 1989; Bobzin and Faulkner 1991; Wahl and Sönnichsen 1992; Becker and Wahl 1996; Hellio et al. 2009). Among these organisms, marine algae produce a wide variety of chemically active metabolites, potentially as an aid to protect themselves against other settling organisms that could prevent or reduce access to light and nutrients (Henrikson and Pawlik 1995; Wahl 2008; Hellio et al. 
2009). Active metabolites from several species of marine macro- and microalgae are reported as antibacterial, antifungal, antialgal and/or antimacrofouling agents that are effective in the prevention of biofouling (Fusetani 2004; Maréchal et al. 2004; Barbosa et al. 2007; Tsoukatou et al. 2007; Cassano et al. 2008; Culioli et al. 2008; da Gama et al. 2008; Mokrini et al. 2008; Plouguerné et al. 2010).

The production of defensive compounds can vary in a number of forms: seasonal, within species, within populations, within thallus or geographically. This has already been recorded for characteristic brown algae defensive metabolites: terpenes and phlorotannins. Vallim et al. (2005) revealed that the geographical distribution of Dictyotacean diterpenes is parallel to geographical and chemical differentiation. Qualitative variation in diterpene composition among populations of the brown seaweed Stypopodium zonale has also been recorded (e.g. Pereira et al. 2004). Concerning phlorotannins, their total content in algae has been shown to depend on environmental factors such as salinity, light and nutrient availability (Amsler and Fairhead 2006; Jormalainen and Honkanen 2008). Variation of total phlorotannin content seems to occur among local populations of algae (Pavia et al. 1999; Hemmi and Jormalainen 2004; Koivikko et al. 2008). Such variation can be explained by genetic differentiation among populations and/or response to local changes of environmental factors (Koivikko et al. 2008).

Among the Phaeophyceae, the genus Sargassum is well known to produce compounds with antioxidant, antibacterial, antitumoral, antimalarial, antiherbivory and antifouling (AF) properties (Amsler and Fairhead 2006; Rastian et al. 2007; Afolayan et al. 2008; Heo and Jeon 2009; Plouguerné et al. 2010). Rather than screening among a wide variety of different species of macroalgae for AF activity (e.g. da Gama et al. 2008), the present study focussed on investigating how AF activity varies within a single species of the genus Sargassum. With this goal, AF potency of several populations of Sargassum vulgare C. Agardh from various locations was assessed. This brown alga is very abundant along the coast of Rio de Janeiro state (Brazil, western Atlantic). Populations of this alga play an important ecological role, providing different resources and shelter to members of the marine community (Széchy et al. 2006).

\section{Material and methods}

In order to investigate potential spatial variations in chemical defence production, $S$. vulgare was collected at five locations along the coast of Rio de Janeiro state, extracted using methanol, dichloromethane, hexane and acetone $/ \mathrm{H}_{2} \mathrm{O}(1 / 1)$ as solvents and screened for $\mathrm{AF}$ activities against marine fouling bacteria, biofilm-associated microphytobenthic strains and the mussel Perna perna.

Seaweed sampling and extract preparation

Thalli of $S$. vulgare were collected in October 2008, by hand at low tide or while free diving in the shallow subtidal zone from the five collection sites, spread from the north to the south of the coast of the state of Rio de Janeiro: Mar do Norte (Rio das Ostras municipality; $22^{\circ} 31^{\prime} \mathrm{S}, 41^{\circ} 51^{\prime} \mathrm{W}$ ), Praia da Tartaruga (Rio das Ostras; $22^{\circ} 31^{\prime} \mathrm{S}, 41^{\circ} 57^{\prime} \mathrm{W}$ ), Praia Rasa (Búzios; $22^{\circ} 44^{\prime} \mathrm{S}, 41^{\circ} 57^{\prime} \mathrm{W}$ ), Bananal (Niterói; $22^{\circ} 58^{\prime} \mathrm{S}, 43^{\circ} 01^{\prime} \mathrm{W}$ ) and Ilha de Itacuruçá (Mangaratiba; $22^{\circ} 56^{\prime} \mathrm{S}, 43^{\circ} 52^{\prime} \mathrm{W}$; Fig. 1). After collection, specimens were immediately transferred to the laboratory in insulated containers, where they were gently washed in seawater, sorted and cleaned of associated biota and then immersed for $30 \mathrm{~s}$ in absolute ethanol to remove associated microflora (Plouguerné et al. 2008). Algae were freeze-dried and ground to a powder before extraction. For each site, four different extractions were carried out using hexane, dichloromethane, methanol and acetone/water (1/1), the latter one for the extraction of polyphenols. All extracts were conducted using $20 \mathrm{~mL}$ of solvent $\mathrm{g}^{-1}$ alga (dry weight, DW). The mixture was then filtered, solvents eliminated under reduced pressure $\left(<40^{\circ} \mathrm{C}\right)$ and freezedried. The remainder was then weighed and stored at $-15^{\circ}$ $\mathrm{C}$ prior to bioassays.

\section{Antibacterial assays}

Algal extracts were tested for inhibitory activity against five strains of biofilm-forming marine bacteria obtained from the collection of the University of Portsmouth (School of Biological Sciences): Vibrio aestuarianus Tison et Seidler 1983 (ATCC 35048), Pseudoalteromonas elyakovii (Ivanova et al. 1997) Sawabe et al. 2000 (ATCC 700519), Polaribacter irgensii Gosink et al. 1998 (ATCC 700398), Vibrio anguillarum Bergeman 1909 (ATCC 19264) and Vibrio natriegens (Payne et al. 1961) Baumann et al. 1981 (ATCC 33788). Each treatment and control (culture media) was replicated six times. Extracts (at concentrations of $0.2,2,20,125,250$ and $500 \mu \mathrm{g} \cdot \mathrm{mL}^{-1}$ ) were incubated with the bacteria $\left(2.108\right.$ cells. $\left.\mathrm{mL}^{-1}\right)$ in 96 wellplates (VWR) in LB medium (Luria Hinton Broth, Sigma, UK), supplemented with $\mathrm{NaCl}\left(35 \mathrm{~g} \cdot \mathrm{L}^{-1}\right)$, at $30^{\circ} \mathrm{C}$ for $72 \mathrm{~h}$ as previously described in Maréchal et al. (2004). Bacterial strains were maintained on agar plates (LB medium, $\mathrm{NaCl}=35$ g. $\mathrm{L}^{-1}$, agar=15\%). Minimum inhibitory concentrations (MICs) compared to the control were determined by the microtitre broth dilution method (Amsterdam 1996; Plouguerné et al. 2008; Plouguerné et al. 2010). 


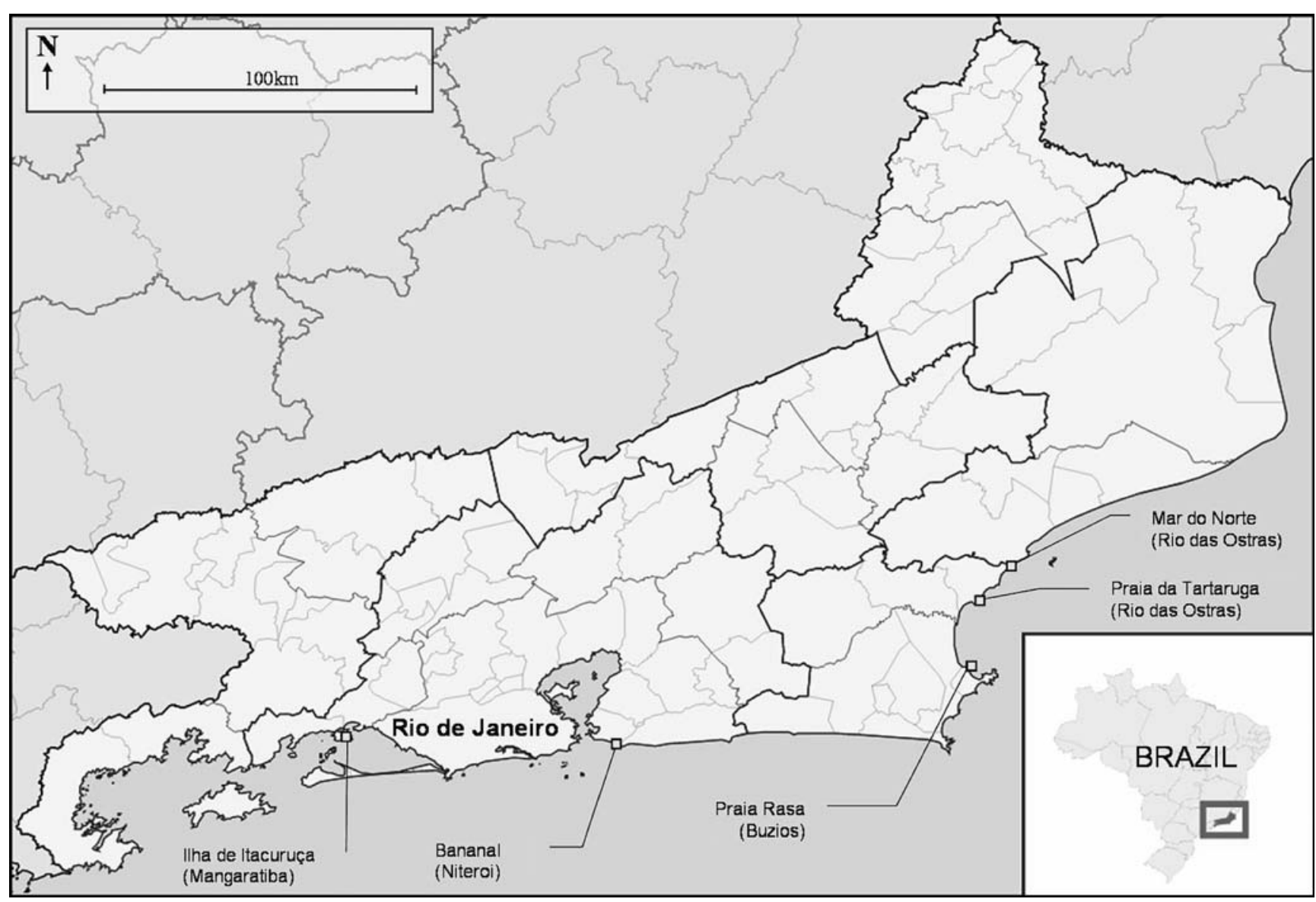

Fig. 1 Localisation of the collection sites of $S$. vulgare along the coast of Rio de Janeiro State

\section{Antimicroalgal assays}

All algal extracts were tested for inhibitory activity against the benthic phase of five strains of marine microalgae obtained from Algobank-Caen (AC; Université de Caen Basse-Normandie, France): Cylindrotheca closterium Reimann and Lewin (1964) (AC170), Chlorarachnion globosum K. Ishida and Y. Hara (1994) (AC132), Pleurochrysis roscoffensis (Dangeard) Fresnel and Billard (1991) (AC32), Rhodella cyanea C. Billard and J. Fresnel (1986) (AC125) and Scenedesmus armatus (Chodat) Chodat (1913) (AC147). All microalgal cultures and assays were kept at controlled conditions (temperature at $23 \pm 2^{\circ} \mathrm{C}$ with $54 \mu \mathrm{mol}$ photons $\cdot \mathrm{m}^{-2} \cdot \mathrm{s}^{-1}$ cool-white fluorescent lamp). $\mathrm{F} / 2$ medium (Guillard and Ryther 1962) was used for their cultivation. Stock strains were maintained on agar plates ( $\mathrm{F} / 2$ with $12.5 \%$ agar). Microalgae for AF assays were cultivated as outlined by Tsoukatou et al. (2002). All the experiments were carried out in six replicates. For this, $100 \mu \mathrm{L}$ of a culture at $0.4 \mu \mathrm{g} . \mathrm{mL}^{-1}$ of chlorophyll- $a$ was introduced in 96-well plates containing the extracts (at concentrations of $0.2,2,20,125,250$ and $500 \mu \mathrm{g} . \mathrm{mL}^{-1}$ ) (Plouguerné et al. 2010). After 48 h, MICs were determined by comparison of the cell growth in the treatments and controls (Tsoukatou et al. 2002).

\section{P. perna antifouling assays}

Extracts from $S$. vulgare were tested in laboratory bioassays against the brown mussel P. perna (Linnaeus 1758). Mussels are relevant fouling organisms in an ecological context, as they frequently colonise seaweeds (Petersen 1984; Eyster and Pechenik 1988; Davis and Moreno 1995; Lasiak and Barnard 1995; Alfaro et al. 2004). Juvenile mussels were collected during low tide from the rocky coast of Itaipu (Niterói, Rio de Janeiro) and kept in a 400-L laboratory aquarium equipped with biological filtering, protein skimming and activated carbon at constant temperature $\left(20^{\circ} \mathrm{C}\right)$, salinity (35 PSU) and aeration for $12 \mathrm{~h}$. The mussels were then carefully disaggregated by cutting the byssal threads. Those exhibiting substratum exploring behaviour (actively exposing their foot) were selected. AF activity was measured by the procedure described in da Gama et al. (2003). Water-resistant filter paper was cut into 9-cm diameter circles and soaked in solvent (control filters). Another 9-cm diameter set of filters (treatment filters) was 
cut in a chess board pattern (1-cm squares) and soaked in a natural concentration of extracts (the extract equivalent to the DW of algae $=\mathrm{DW}$ of filter paper). All filters were allowed to air-dry. Entire filters were placed in the bottom of sterile polystyrene Petri dishes, over which treated chess board filters were placed. Dishes were filled with $80 \mathrm{~mL}$ of seawater and three juvenile mussels (1.5-2.5 cm length) added. In this way, mussels would have the same area of treated (superior, squared) and control (inferior, entire) substrata on which to attach. A total of ten replicates per treatment were used. Experiments were kept in darkness, as mussels have been shown to produce more byssal threads in the dark (Davis and Moreno 1995). Mussel attachment was recorded $24 \mathrm{~h}$ after the start of the experiment. Mussels were then tagged according to treatment and suspended in the aquarium for $24 \mathrm{~h}$ to check for possible mortality due to exposure to the test substances.

\section{Statistical analysis}

To satisfy the criteria of normality and variance homogeneity, data were transformed using the square root of $X+1$ prior to ANOVA. Dunnett's one-tailed test was used for post hoc comparisons with controls when the ANOVA indicated significant differences. We adopted the 0.05 significance level $(\alpha=5 \%)$.

Table 1 Results of the bioassays for the antifouling activity of $S$. vulgare extracts

The numbers associated with I, $\mathrm{B}, \mathrm{R}, \mathrm{T}$ or $\mathrm{N}$ represent the extraction solvent: $1=$ methanol, $2=$ dichloromethane, 3 = hexane, $4=$ acetone/distilled water $(1 / 1$; used for the extraction of polyphenols). For bacteria and microalgae, the minimal inhibitory concentrations are expressed in $\mu \mathrm{g} . \mathrm{mL}^{-1}$

$B 1$ V. aestuarianus, $B 2 P$. elyakovii, B3 P. irgensii, B4 V. anguillarum, B5 $V$. natriegens, M1 C. closterium, M2 C. globosum, M3 P. roscoffensis, M4 R. cyanea, M5 S. armatus, I Ilha de Itacuruçá, $B$ Bananal, $R$ Praia Rasa, $T$ Praia da Tartaruga, $N$ Mar do Norte, + represents significant inhibition at natural concentrations relative to controls for mussels (see Fig. 2), - represents no inhibition

\section{Results}

Antibacterial assays

Of the $20 \mathrm{~S}$. vulgare extracts tested, four had antibacterial activities: the methanol extract from Mar do Norte (N1), the dichloromethane extract from Mar do Norte (N2), the hexane extract from Ilha de Itacuruçá (I3) and the polyphenol extract from Mar do Norte (N4; Table 1). The most active extract was the methanol extract from Mar do Norte (N1) which inhibited $V$. aestuarianus (B1) and P. elyakovii (B2) at MICs of $0.2 \mu \mathrm{g} \cdot \mathrm{mL}^{-1}$. Of the two bacterial strains inhibited by $S$. vulgare extracts, V. aestuarianus (B1) appeared to be the most sensitive, showing inhibition of its growth by four extracts. P. elyakovii (B2) was only sensitive to the hexane and dichloromethane extracts from Mar do Norte (N1 and $\mathrm{N} 2$, respectively).

\section{Antimicroalgal assays}

Antimicroalgal activity was detected from all the extracts tested. The hexane extract from $S$. vulgare collected from Bananal (B3) inhibited the growth of all the microalgae tested, with MICs in the range of 20 to $500 \mu \mathrm{g} \cdot \mathrm{mL}^{-1}$ (Table 1). The hexane extract from Praia da Tartaruga (T3), Mar do Norte (N3) and the polyphenol extract from Ilha de

\begin{tabular}{|c|c|c|c|c|c|c|c|c|c|c|c|}
\hline \multirow[b]{3}{*}{ Extract } & \multicolumn{10}{|c|}{ Microfouling } & \multirow{3}{*}{$\begin{array}{l}\text { Macrofouling } \\
\text { Perna perna }\end{array}$} \\
\hline & \multicolumn{5}{|c|}{ Biofilm-forming marine bacteria } & \multicolumn{5}{|c|}{ Marine microalgae } & \\
\hline & $\mathrm{B} 1$ & B2 & B3 & B4 & B5 & M1 & M2 & M3 & M4 & M5 & \\
\hline I1 & - & - & - & - & - & 2 & - & 0.2 & 0.2 & - & + \\
\hline B1 & - & - & - & - & - & 0.2 & - & 0.2 & 250 & - & + \\
\hline $\mathrm{R} 1$ & - & - & - & - & - & 0.2 & - & 250 & 125 & - & + \\
\hline $\mathrm{T} 1$ & - & - & - & - & - & - & - & 0.2 & 20 & - & + \\
\hline N1 & 0.2 & 0.2 & - & - & - & - & - & 0.2 & 250 & - & + \\
\hline I2 & - & - & - & - & - & - & - & 2 & 2 & - & - \\
\hline B2 & - & - & - & - & - & - & 250 & 0.2 & 500 & - & - \\
\hline R2 & - & - & - & - & - & - & 250 & 0.2 & 125 & - & + \\
\hline $\mathrm{T} 2$ & - & - & - & - & - & 500 & - & - & 0.2 & - & - \\
\hline $\mathrm{N} 2$ & 0.2 & 2 & - & - & - & 0.2 & - & - & 500 & - & - \\
\hline I3 & 2 & - & - & - & - & 500 & - & - & - & 500 & - \\
\hline B3 & - & - & - & - & - & 500 & 250 & 20 & 500 & 500 & - \\
\hline R3 & - & - & - & - & - & - & - & 500 & 250 & 125 & - \\
\hline T3 & - & - & - & - & - & 500 & 250 & - & 2 & 500 & + \\
\hline $\mathrm{N} 3$ & - & - & - & - & - & 20 & 500 & - & 0.2 & 20 & - \\
\hline I4 & - & - & - & - & - & 125 & 20 & 0.2 & 125 & - & + \\
\hline B4 & - & - & - & - & - & 2 & - & 0.2 & - & - & + \\
\hline R4 & - & - & - & - & - & 0.2 & - & 0.2 & - & - & - \\
\hline $\mathrm{T} 4$ & - & - & - & - & - & 2 & 250 & - & - & - & - \\
\hline N4 & 125 & - & - & - & - & - & - & 20 & 500 & 500 & - \\
\hline
\end{tabular}


Itacuruça (I4) inhibited the growth of four of the five microalgae tested, with minimal MICs of $2 \mu \mathrm{g} \cdot \mathrm{mL}^{-1}$ (T3 vs M4) and $0.2 \mu \mathrm{g} . \mathrm{mL}^{-1}$ (N3 vs M4, I4 vs M3). The methanol extracts from Ilha de Itacuruçá (I1), Bananal (B1), Praia Rasa (R1), the dichloromethane extracts from Bananal (B2), Praia Rasa (R2) and the polyphenol extract from Mar do Norte exhibited antimicroalgal activity against three of the five species tested. The minimal MICs recorded were $0.2 \mu \mathrm{g} . \mathrm{mL}^{-1}$ (I1 vs M3, I1 vs M4, B1 vs M1, B1 vs M3, R1 vs M1, B2 vs M3, R2 vs M3) and $20 \mu \mathrm{g} \cdot \mathrm{mL}^{-1}$ (N4 vs M3). All the other extracts inhibited two of the five species tested.

$R$. cyanea (M4) appears to be the most sensitive to $S$. vulgare compounds; 16 of the 20 extracts tested inhibited its growth. Microalgae can be classified from the most to the least sensitive to the extracts as follows: M4 > M3 > M1 > M2 > M5.

\section{P. perna antifouling assays}

Among the 20 extracts tested at natural concentration, nine exhibited a significant inhibition of mussel attachment relative to controls (Fig. 2). The extracts that exhibited the strongest AF activity were the acetone $/ \mathrm{H}_{2} \mathrm{O}(1 / 1)$ extracts from Ilha de Itacuruçá $(p=0.0002)$ and Bananal $(p=$ 0.00004 ) that inhibited $64 \%$ and $71 \%$, respectively, of the $P$. perna attachment. All methanolic extracts showed significant AF activity: Bananal $(p=0.0179)$, Praia Rasa $(p=0.0157)$, Praia da Tartaruga $(p=0.0045)$, Ilha de Itacuruçá $(p=0.0013)$ and Mar do Norte $(p=0.0004)$. From the hexane and dichloromethane extracts, only two inhibited the attachment of $P$. perna: the hexane extract from Ilha de Itacuruçá $(p=0.0365)$ and the dichloromethane extract from Praia Rasa $(p=0.0086)$. Extracts were not acutely toxic to mussels since no mortality was recorded across all treatments during the experiments or in the $24 \mathrm{~h}$ following exposure to test extracts (data not shown).

\section{Discussion}

The process of marine biofouling can be separated in two steps: microfouling, constituted by the initial settlement and development of microorganisms such as bacteria fungi and microalgae, and macrofouling, comprising the settlement of macrofoulers such as barnacles, tubeworms and mussels (Wahl 1989; Hölmstrom and Kjelleberg 1994; Callow and Callow 2002; Maki 2002; Dobretsov et al. 2006; Qian et al.

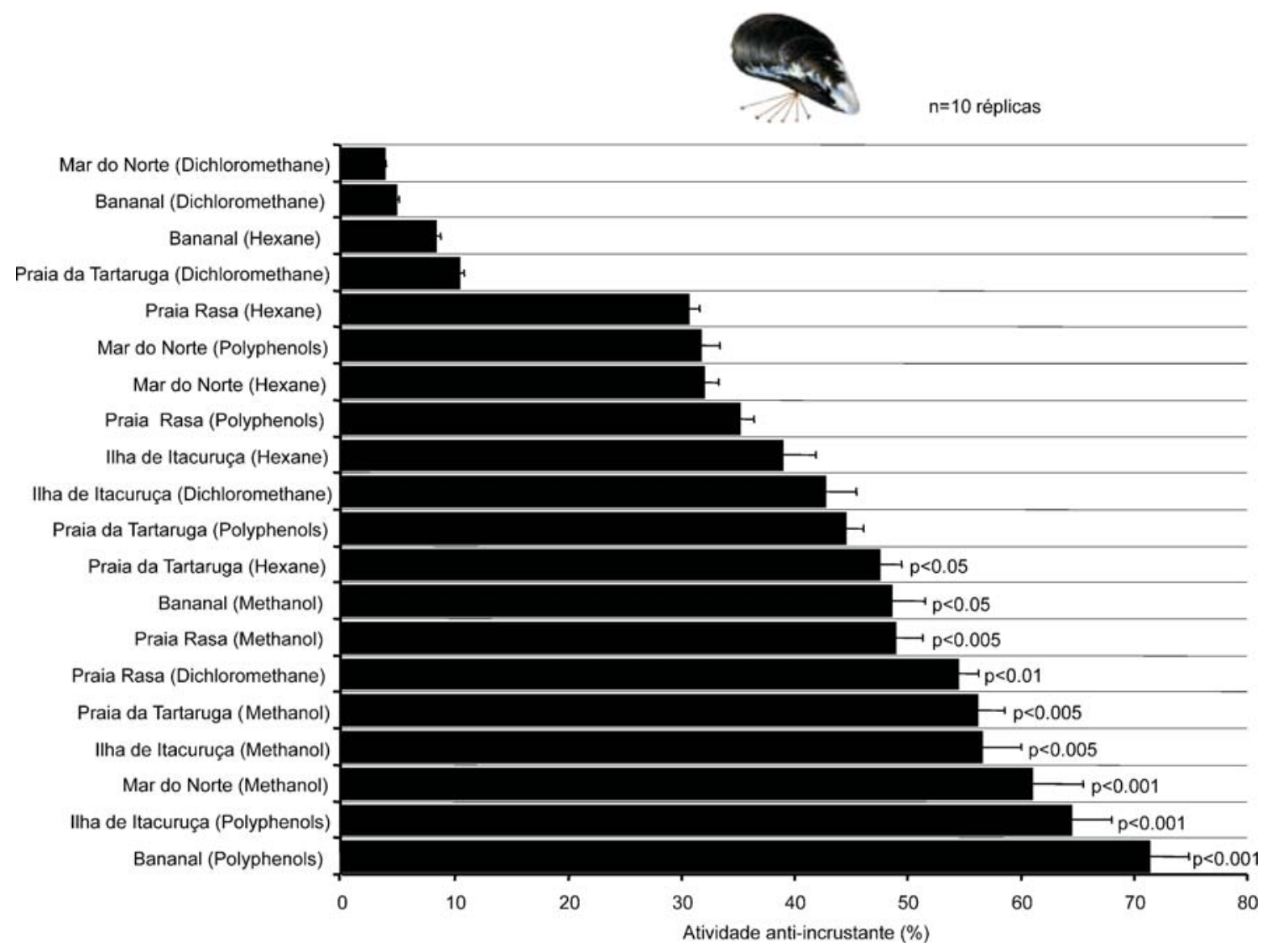

Fig. 2 Antifouling activity (\% inhibition relative to mussel byssal attachment in controls) of $S$. vulgare extracts. In total, ten replicates per treatment were carried out. Significant results are indicated whenever $p<0.05$ 
2007). The prevention of marine fouling is therefore linked to the control of settlement and growth of the fouling organisms constituting both microfouling and macrofouling communities.

Our work achieved interesting results in terms of inhibition of one of the major agents involved in the microfouling formation. Indeed, $56 \%$ of the extracts tested from $S$. vulgare showed inhibition of microalgal growth. Considering only diatoms and coccolithophores (C. closterium and P. roscoffensis), this percentage rises to $67.5 \%$. Tanaka and Asakawa (1988) described antimicroalgal activities from the Japanese alga Sargassum horneri against diatoms, and Wang et al. $(2006,2007)$ reported the antimicroalgal effect of Sargassum thunbergii from the coast of China against Skeletonema costatum and dinoflagellates. The occurrence of diatoms at the surface of Brazilian Sargassaceae has been described (Moreira and de Oliveira, 1976), and results suggest that such epibionts may act as important agents in the evolution of $S$. vulgare secondary metabolites. No major geographic variation of the antimicroalgal activity was observed as at least two of the five microalgae tested were inhibited by each extract. Such results seem to indicate that microalgae exert a fouling pressure at every field site.

Both toxic and environmentally friendly AF paints tend to be effective against most fouling organisms, yet fail badly to inhibit diatom slimes (Molino and Wetherbee 2008). The hexane extracts were the most active inhibiting the growth of microalgae in $72 \%$ of the tests. Such observation led us to hypothesise that $S$. vulgare may produce non-polar compounds involved in the specific defence against microalgae. Plouguerné et al. (2010) identified polyunsaturated fatty acids from Sargassum muticum as antimicroalgal agents. Investigate the presence and the role of such compounds at the surface of $S$. vulgare is a logical next step.

Concerning the antibacterial activity, only $6 \%$ of the tested extracts showed growth inhibition. Nevertheless, some extracts such as the methanol (N1) and dichloromethane (N2) extracts of $S$. vulgare from Mar do Norte were active against $V$. aestuarianus and $P$. elyakovii. The former one is a pathogen-causing mortalities in bivalves, particularly the Pacific oyster Crassostrea gigas (Paillard et al. 2004). P. elyakovii has been identified as the causative bacterium of Laminaria spot wound disease in Japan (Narita et al. 2001). These two bacteria pose a threat to aquaculture, causing severe drops in oyster and seaweed production (Garnier et al. 2007; Vairappan et al. 2008). The economical importance of the bacterial strains inhibited, as well as the low MICs registered (0.2 to $\left.2 \mu \mathrm{g} \cdot \mathrm{mL}^{-1}\right)$, emphasises the results observed for N1 and N2. Indeed, these extracts may constitute a source of natural chemotherapy for aquaculture. Moreover, antimicrobial com- pounds from marine organisms are generally stable in seawater (Relf et al. 1999; Tincu and Taylor 2004). Therefore, such natural compounds would be preferred to traditional antibiotics, sensitive to saline conditions (Desbois et al. 2009). The antimicrobial activity of $S$. vulgare extracts presented geographical variation: only algae from Mar do Norte and Ilha de Itacuruçá demonstrated activity. This is, however, difficult to interpret (e.g. as a correlation with environmental factors) since these sites are geographically distant and distinct with concern to environmental factors: Mar do Norte is an open, wave-exposed coast, while Ilha de Itacuruçá is a sheltered place inside an estuarine bay (Baía de Sepetiba).

Concerning the macrofouling experiments using mussels, all the methanolic extracts were inhibitory. Mussels were observed attached to $S$. vulgare thalli at all sites. Such constant pressure may have influenced the selection of a specific chemical defence based on polar metabolite(s), as suggested by the activity of the methanolic extracts. On the other hand, the results observed for the hexane and polyphenol extracts were dependent on the collection site. Such geographical variations in antifouling activity may be explained by different local environmental conditions. Indeed, factors such as salinity, light, UV, grazing, temperature, hydrodynamism or nutrients are known to influence chemical defence production in brown seaweeds (Hemmi et al. 2004; Macaya et al. 2005; Wiencke et al. 2007; Yun et al. 2007), although the specific mechanisms involved are still largely unknown.

Acknowledgements We are grateful to Dr. Maria Thereza Menezes de Széchy from the Universidade Federal do Rio de Janeiro (UFRJ) for her help in setting up the collection of Sargassum vulgare. The work was supported financially by the Fundação de Amparo à Pesquisa do Estado do Rio de Janeiro (FAPERJ; protocol no. E-26/ 101.649/2008). BAP da Gama and RC Pereira benefit from Research Productivity fellowships awarded by CNPq.

\section{References}

Afolayan AF, Bolton JJ, Lategan CA, Smith PJ, Beukes DR (2008) Fucoxanthin, tetraprenylated toluquinone and toluhydroquinone metabolites from Sargassum heterophyllum inhibit the in vitro growth of the malaria parasite Plasmodium falciparum. Z Naturforsch (C) 63:848-852

Alfaro AC, Jeffs AG, Creese RG (2004) Bottom-drifting algal/mussel spat associations along a sandy coastal region in northern New Zealand. Aquaculture 241:269-290

Amsler CD, Fairhead VA (2006) Defensive and sensory chemical ecology of brown algae. In: Callow JA (ed) Advances in botanical research. Academic, London, pp 1-91

Amsterdam D (1996) Susceptibility testing of antimicrobials in liquid media. In: Lorian V (ed) Antibiotics in laboratory medicine. Williams and Wilkins, Baltimore, pp 52-111

Barbosa JP, Fleury BG, Da Gama BAP, Teixeira VL, Pereira RC (2007) Natural products as antifoulants in the Brazilian brown 
alga Dictyota pfaffii (Phaeophyta, Dictyotales). Biochem Syst Ecol 35:549-553

Becker K, Wahl M (1996) Behaviour patterns as natural antifouling mechanisms of tropical marine crabs. J Exp Mar Biol Ecol 203:245-258

Bobzin SC, Faulkner DJ (1991) Diterpenes from the Pohnpeian marine sponge Chlenolaplysilla. J Nat Prod 54:225-232

Callow ME, Callow JA (2002) Marine biofouling: a sticky problem. Biologist 49:1-5

Cassano V, De-Paula JC, Fujii MT, Da Gama BAP, Teixeira VL (2008) Sesquiterpenes from the introduced red seaweed Laurencia caduciramulosa (Rhodomelaceae, Ceramiales). Biochem Syst Ecol 36:223-226

Culioli G, Ortalo-Magné A, Valls R, Hellio C, Clare AS, Piovetti L (2008) Antifouling activity of meroditerpenoids from the marine brown alga Halidrys siliquosa. J Nat Prod 71:1121-1126

Da Gama BAP, Pereira RC, Soares AR, Teixeira VL, YoneshigueValentin Y (2003) Is the mussel test a good indicator of antifouling activity? A comparison between laboratory and field assays. Biofouling 19:161-169

Da Gama BAP, Carvalho AGV, Weidner K, Soares AR, Coutinho R, Fleury BG, Teixeira VL, Pereira RC (2008) Antifouling activity of natural products from Brazilian seaweeds. Bot Mar 51:191-201

Davis AR, Moreno CA (1995) Selection of substrata by juvenile Choromytilus chorus (Mytilidae): are chemical cues important? J Exp Mar Biol Ecol 191:167-180

Davis AR, Targett NM, McConnell OJ, Young CM (1989) Epibiosis of marine algae and benthic invertebrates: natural products chemistry and other mechanisms inhibiting settlement and overgrowth. Bioorg Mar Chem 3:85-114

Desbois AP, Mearns-Spragg A, Smith VJ (2009) A fatty acid from the diatom Phaeodactylum tricornutum is antibacterial against diverse bacteria including multi-resistant Staphylococcus aureus (MRSA). Mar Biotechnol 11:45-52

Dobretsov S, Dahms HU, Qian PY (2006) Inhibition of biofouling by marine microorganisms and their metabolites. Biofouling 22:4354

Eyster LS, Pechenik JA (1988) Attachment of Mytilus edulis L. larvae on algal and byssal filaments is enhanced by water agitation. $\mathrm{J}$ Exp Mar Biol Ecol 114:99-110

Fusetani N (2004) Biofouling and antifouling. Nat Prod Rep 21:94-104

Garnier M, Labreuche Y, Garcia C, Robert M, Nicolas JL (2007) Evidence for the involvement of pathogenic bacteria in summer mortalities of the pacific oyster Crassostrea gigas. Microb Ecol 53:187-196

Guillard RRL, Ryther JH (1962) Studies of marine planktonic diatoms. I. Cyclotella nana Hustedt and Detonula confervacea Cleve. Can J Microbiol 8:229-239

Hellio C, Yebra DM (eds) (2009) Advances in marine antifouling coatings and technologies. Woodhead, Cambridge

Hellio C, Maréchal JP, da Gama BAP, Pereira RC, Clare AS (2009) Natural marine products with antifouling activities. In: Hellio C, Yebra D (eds) Advances in marine antifouling coatings and technologies. Woodhead, Cambridge, pp 572-622

Hemmi A, Jormalainen V (2004) Geographic covariation of chemical quality of the host alga Fucus vesiculosus with fitness of the herbivorous isopod Idotea baltica. Mar Biol 145:759-768

Hemmi A, Honkanen T, Jormalainen V (2004) Inducible resistance to herbivory in Fucus vesiculosus - duration, spreading and variation with nutrient availability. Mar Ecol Prog Ser 273:109-120

Henrikson AA, Pawlik JR (1995) A new antifouling assay method: results from field experiments using extracts of four marine organisms. J Exp Mar Biol Ecol 194:157-165

Heo SJ, Jeon YJ (2009) Protective effect of fucoxanthin isolated from Sargassum siliquastrum on UV-B induced cell damage. J Photochem Photobiol B 95:101-107
Hölmstrom C, Kjelleberg S (1994) The effect of external biological factors on settlement of marine invertebrates and new antifouling technology. Biofouling 8:147-160

Jormalainen V, Honkanen T (2008) Macroalgal chemical defenses and their roles in structuring temperate marine communities. In: Amsler CD (ed) Algal chemical ecology. Springer, Berlin, pp 57-89

Koivikko R, Eranen JK, Loponen J, Jormalainen V (2008) Variation of phlorotannins among three populations of Fucus vesiculosus as revealed by HPLC and colorimetric quantification. J Chem Ecol 34:57-64

Lasiak TA, Barnard TCE (1995) Recruitment of the brown mussel Perna perna onto natural substrata: a refutation of the primary/ secondary settlement hypothesis. Mar Ecol Prog Ser 120:147153

Macaya EC, Rothausler E, Thiel M, Molis M, Wahl M (2005) Induction of defenses and within-alga variation of palatability in two brown algae from the northern-central coast of Chile: effects of mesograzers and UV radiation. J Exp Mar Biol Ecol 325:214 227

Maki J (2002) Biofouling in the marine environment. In: Bitton H (ed) Encyclopedia of environmental microbiology. Wiley, New York, pp 610-619

Maréchal JP, Culioli G, Hellio C, Thomas-Guyon H, Callow ME, Clare AS, Ortalo-Magne A (2004) Seasonal variation in antifouling activity of crude extracts of the brown alga Bifurcaria bifurcata (Cystoseiraceae) against cyprids of Balanus amphitrite and the marine bacteria Cobetia marina and Pseudoalteromonas haloplanktis. J Exp Mar Biol Ecol 313:47-62

Mokrini R, Ben Mesaoud M, Daoudi M, Hellio C, Maréchal JP, El Hattab M, Ortalo-Magne A, Piovetti L, Culioli G (2008) Meroditerpenoids and derivatives from the brown alga Cystoseira baccata and their antifouling properties. J Nat Prod 71:1806-1811

Molino PJ, Wetherbee R (2008) The biology of biofouling diatoms and their role in the development of microbial slimes. Biofouling 24:365-379

Moreira H, de Oliveira EC (1976) Epiphytic diatoms in two populations of Sargassum cymosum. Acta Biol Par 5:53-75

Narita M, Sawabe T, Gacesa P, Ezura Y (2001) Rapid PCR detection of Pseudoalteromonas elyakovii, the causative bacterium of Laminaria spot wound disease in Japan. In: Chapman ARO, Anderson RJ, Vreeland VJ, Davison IR (eds) Proceedings of the seventeenth international seaweed symposium. Oxford University Press, London, pp 389-394

Paillard C, Le Roux F, Borrego JJ (2004) Bacterial disease in marine bivalves, a review of recent studies: trends and evolution. Aquat Living Res 17:477-498

Pavia H, Toth G, Åberg P (1999) Trade-offs between phlorotannin production and annual growth in natural populations of the brown seaweed Ascophyllum nodosum. J Ecol 87:761-771

Pereira RC, Soares AR, Teixeira VL, Villaça RC, da Gama BAP (2004) Variation on chemical defenses against herbivory in southwestern Atlantic Stypopodium zonale (Phaeophyta). Bot Mar 47:202-208

Petersen JH (1984) Larval settlement behavior in competing speciesMytilus californianus Conrad and Mytilus edulis L. J Exp Mar Biol Ecol 82:147-159

Plouguerné E, Hellio C, Deslandes E, Véron B, Stiger-Pouvreau V (2008) Anti-microfouling activities of extracts of two invasive algae: Grateloupia turuturu and Sargassum muticum. Bot Mar 51:202-208

Plouguerné E, Ioannou E, Georgantea P, Vagias C, Roussis V, Hellio C, Kraffe E, Stiger-Pouvreau V (2010) Anti-microfouling activity of lipidic metabolites from the invasive brown alga Sargassum muticum (Yendo) Fensholt. Mar Biotech 12:52-61 
Qian PY, Lau SCK, Dahms HU, Dobretsov S, Harder T (2007) Marine biofilms as mediators of colonization by marine macroorganisms: implications for antifouling and aquaculture. Mar Biotechnol 9:399-410

Rastian Z, Mehranian M, Vahabzadeh F, Sartavi K (2007) Antioxidant activity of brown algae Sargassum vulgare and Sargassum angustrifolum. J Aquat Food Prod Technol 16:17-26

Relf JM, Chisholm JR, Kemp GD, Smith VJ (1999) Purification and characterization of a cysteine-rich $11.5 \mathrm{kDa}$ antibacterial protein from the granular haemocytes of the shore crab, Carcinus maenas. Eur J Biochem 264:350-357

Steinberg PD, de Nys R, Kjelleberg S (2002) Chemical cues for surface colonization. J Chem Ecol 28:1935-1951

Stoecker D (1978) Resistance of a tunicate to fouling. Biol Bull 155:615-626

Széchy MTM, Galliez M, Marconi MI (2006) Quantitative variables applied to phenological studies of Sargassum vulgare C. Agardh (Phaeophyceae-Fucales) from Ilha Grande Bay, State of Rio de Janeiro. Revista Brasil Bot 29:27-37

Tanaka N, Asakawa A (1988) Allelopathic effect of mucilage released from a brown alga Sargassum horneri on marine diatoms. Nippon Suisan Gakk 54:1711-1714

Tincu JA, Taylor SW (2004) Antimicrobial peptides from marine invertebrates. Antimicrob Agents Chemother 48:3645-3654

Tsoukatou M, Hellio C, Vagias C, Harvala C, Roussis V (2002) Chemical defense and antifouling activity of three Mediterranean sponges of the genus Ircinia. Z Naturforsch 57:161-171

Tsoukatou M, Maréchal JP, Hellio C, Novaković I, Tufegdzic S, Sladić D, Gašić MJ, Clare AS, Vagias C, Roussis V (2007) Evaluation of the activity of the sponge metabolites avarol and avarone and their synthetic derivatives against fouling micro- and macroorganisms. Molecules 12:1022-1034
Vairappan C, Chung C, Hurtado A, Soya F, Lhonneur G, Critchley A (2008) Distribution and symptoms of epiphyte infection in major carrageenophyte-producing farms. J Appl Phycol 20:477-483

Vallim MA, De Paula JC, Pereira RC, Teixeira VL (2005) The diterpenes from Dictyotacean marine brown algae in the Tropical Atlantic American region. Biochem Syst Ecol 33:1-16

Wahl M (1989) Marine epibiosis. I. Fouling and antifouling: some basic aspects. Mar Ecol Prog Ser 58:175-189

Wahl M (2008) Ecological lever and interface ecology: epibiosis modulates the interactions between host and environment. Biofouling 24:427-438

Wahl M, Sönnichsen H (1992) Marine epibiosis. IV. The periwinkle Littorina littorea lacks typical antifouling defenses-why are some populations so little fouled? Mar Ecol Prog Ser 88:225235

Wang R, Tang X, Feng L, Xiao H, Qu L, Cai H (2006) Inhibitory effect of Sargassum thunbergii on Heterosigma akashiwo and Skeletonema costatum. J Appl Phycol 17:2421-2425

Wang R, Xiao H, Zhang P, Qu L, Cai H, Tang X (2007) Allelopathic effects of Ulva pertusa, Corallina pilulifera and Sargassum thunbergii on the growth of the dinoflagellates Heterosigma akashiwo and Alexandrium tamarense. J Appl Phycol 19:10912

Wiencke C, Luder UH, Roleda MY (2007) Impact of ultraviolet radiation on physiology and development of zoospores of the brown alga Alaria esculenta from Spitsbergen. Physiol Plant 130:601-612

Yun H, Cruz J, Treitschke M, Wahl M, Molis M (2007) Testing for the induction of anti-herbivory defences in four Portuguese macroalgae by direct and water-borne cues of grazing amphipods. Helgol Mar Res 61:203-209 